\title{
An Assessment of Unemployment in Nigeria Before and During Millennium Development Goals (MDGs): Lessons for Post- 2015 Global Development Agenda
}

\author{
Inibehe Nya \\ First City Monument Bank, Port Harcourt, Nigeria \\ Email address: \\ nyainibehe@gmail.com
}

\section{To cite this article:}

Inibehe Nya. An Assessment of Unemployment in Nigeria Before and During Millennium Development Goals (MDGs): Lessons for Post2015 Global Development Agenda. International Journal of Economics, Finance and Management Sciences.

Vol. 9, No. 3, 2021, pp. 119-127. doi: 10.11648/j.ijefm.20210903.14

Received: April 2, 2021; Accepted: April 16, 2021; Published: June 16, 2021

\begin{abstract}
The paper assessed the rate of unemployment before and during the millennium development goals (MDGs). The purpose was to ascertain the extent to which MDGs strategies and programs have assisted in the reduction of unemployment in Nigeria. Secondary data gathered between 1985 and 2018 was used in the evaluation. Findings showed the unemployment rates before the implementation of the MDGs program (1985-1999) were relatively stable at one digit, with the highest rate being $7.1 \%$ in 1987 while the average rate for the referenced period stood at $3.74 \%$. The contrast was the case when MDGs were introduced in the year 2000, in which year the unemployment rate jumped from $3.0 \%$ in 1999 to $26.8 \%$ in 2015 , representing an increase of over 700\%. During the period of the MDGs (2000-2015), unemployment rate assumed two digits, increasing from $13.1 \%$ in 2000 to $26.8 \%$ in 2015 , averaging about $17.7 \%$ with its attendant impact on the livelihood of the average citizen. The sharp rise in unemployment rates during the period of MDGs is a piece of evidence that the MDG programs, despite its laudable objectives, failed to reduce unemployment and eradicate poverty. The reasons for this could be attributed to, but not limited to poor and uncoordinated funding of the program, targets mismatch and absence of monitoring and evaluation (M\&E) of the MDGs projects. The study also revealed that there exists a somewhat positive relationship between unemployment and poverty in Nigeria. The paper recommended among others that MDGs project goals should be measurable, monitored and evaluated, recognize the effect of violence, militancy, and insurgency on development programs and finally, government should vigorously pursue productive employment creation for the realization of its inclusive growth potentials, if the post-2015 Global Development Agenda is to succeed.
\end{abstract}

Keywords: Unemployment, Poverty, Millennium Development Goals (MDGs), Debt Relief

\section{Introduction}

The world economies mostly that of the developing countries, had over the decades, been plagued with myriads of socio- macroeconomic problems such as unemployment, poverty, income inequality, and rising debt profile. Others include inadequate food and shelter, poor access to medical facilities, low literacy level, and environmental degradation. Two of these problems- unemployment and poverty constitute twin developmental challenges that have endured in the developing economies with Nigeria as a reference point.

The Nigerian economy during the 1960 s was primarily an agrarian economy, providing about $70 \%$ of the employment opportunities to the Nigerian populace. During this period, there were forward and backward linkages between agriculture and the manufacturing sector, and employment policies at this time favored labor mobility from the agricultural to the manufacturing sector. As stated by Onwioduokit [15], this appeared to be a natural path of economic growth and development, following the experience of the developed countries.

During the 1960s, average unemployment rates in Nigeria were almost at par or less than those of the more developed economies, however, this position took a dramatic turn in the 1970s when the economy of Nigeria underwent a structural 
transformation to a monocultural oil economy. According to Adedipe [2], the massive increase in oil revenue, accruing to the government of Nigeria created unprecedented, unexpected, and unplanned wealth for Nigeria. Consequently, to make the business environment conducive for new investment, the government began investing the new-found wealth in socio-economic infrastructures in the urban areas at the utter neglect of the rural areas, which resulted in labor mobility to the urban areas, thus exacerbating more pressure on urban unemployment.

For instance, the urban unemployment rate in Nigeria increased from $7.9 \%$ in 1984 to $9.8 \%$ in 1987 while the rural unemployment rate rose from $4.4 \%$ to $6.1 \%$ for the same period. It is important to mention that global unemployment between 2010 and 2011 remained stable at $8 \%$ according to Gallup surveys of 148 countries by Marlar [11] while that of Nigeria grew from $21.1 \%$ in 2010 to $23.9 \%$ in 2011 , and the figure for 2012 stood at $27.4 \%$ against the growth rate estimate of $25 \%$ for 2012 by United States Embassy [23].

The rising profile of unemployment in Nigeria has assumed a disturbing dimension and, this has resulted in the crystallization of a twin developmental problem called poverty, and the associated vices namely, armed robbery, murder, kidnapping, and insurgency. Corroborating this assertion, Akinboyo [3] and Raheem [17], opined that apart from unemployment representing a colossal waste of the country's human resources, it results in welfare loss, in terms of lower output, thereby leading to a lower income and standard of living. Stressing on the import of productive employment, Clinton [5] remarked that the basic fabric of the society cannot be repaired until people who are willing to work have work, emphasizing that work organizes life and gives structure and discipline to life. In the same vein, President Goodluck Jonathan [10], in his presentation of the 2013 budget speech stated that unemployment and poverty constitute an obstacle to sustainable development as they limit improvement in living standards, output, and social cohesion, which are key factors for achieving inclusive growth.

It is against this backdrop that many strategies, policies and programmes had been put in place by successive governments to address the perennial problems of unemployment. These include the National Directorate of Employment (NDE), Poverty Alleviation Programs (PAP) which later changed to National Poverty Eradication Program (NAPEP), and the partnership between government and UNDP that gave birth to the Millennium Development Goals (MDGs) in the year 2000. Nigeria was one of the 189 countries across the various continents of the world that endorsed the United Nations Millennium Development Declaration with eight (8) goals to be achieved before 2015 . The first goal (MDG 1) was the eradication of extreme poverty and hunger. In this paper, our focus is on MDG 1 because it has as one of its targets (1B) the achievement of decent employment for women, men, and young people. It, therefore, presupposes that any meaningful strategy geared at the eradication of extreme poverty and hunger must start with a sincere and concerted effort at tackling unemployment in Nigeria. It has been shown that unemployment is positively correlated with poverty. Grunewald [8], in a study of unemployment and poverty in the US between 1959 and 2004 observed that poverty rates have moved somewhat together with changes in the unemployment rate. This position was corroborated by Umoh [21] that 'There is no way a poor person can sustainably get out of poverty, no matter how broadly defined, without having a means of livelihood, which is employment (paid or self-generated)'. Yet, most documented poverty reduction strategies hardly mention the word 'employment'.

Five years after the set deadline (2015) to achieve the UN Millennium Development Goals (MDGs), the concerns from various quarters remained whether the MDGs have been able to achieve its laudable goals and targets set at the inception, particularly that of providing decent employment to Nigerians and ultimately, eradication of extreme poverty and hunger amongst Nigerians. The purpose of this paper is, therefore, to carry out a qualitative assessment of unemployment before and during the Millennium Development Goals (MDGs). The specific objectives are to examine the nature and trend of unemployment in Nigeria, assess the extent to which MDG goal one is achieved with a focus on target 1B which sought to give employment for men, women and young people. It will also examine the relationship between unemployment and poverty in Nigeria. Policy measures aimed at reducing unemployment will be prescribed and finally, it will provide lessons for the Post2015 Global Development Agenda.

The paper has five sections. Section one is the introduction, while two is the literature review. Section three deals with the theoretical and conceptual framework. Section four dwells on the evaluation of how MDGs have helped to reduce unemployment. Finally, section five is centered on the conclusion and recommendations.

\section{Literature Review}

The concept of unemployment has been defined by scholars from many perspectives in economic literature. The International Labour Organization (ILO) defines unemployment as the numbers of the economically active population who are without work but available for and seeking work, including people who have lost their jobs and those who have voluntarily left work- World Bank [24]. Everyman Dictionary of Economics defines unemployment as involuntary idleness of a person willing to work at the prevailing rate of pay but unable to find it - Jhingan [9]. Corroborating this assertion, Gbosi [7], averred that unemployment is a situation in which people who are willing to work at the prevailing wage rate are unable to find jobs.

Ohale and Onyema [13] defined unemployment (as it applies to labor) as the number of persons within the working-age bracket who are willing and able to work at the prevailing wage rate but cannot find any job involuntary. In the same vein, Adebayo [1] posited that unemployment exists 
when members of the labor force are willing to work but cannot get jobs.

Marx [12] defined unemployment as " the very nature of the capitalist mode of production to overwork some workers while keeping the rest as a reserved army of unemployed paupers". This assertion is commonplace in Nigeria and most developing nations, as most employers of labor subject workers to handle work meant for two or more persons, with a threat of cheap replacement on the basis that there are many jobless graduates roaming the streets begging for jobs.

According to Englama [6], "unemployment rate in an economy is the number of people unemployed, expressed as the percentage of the total labor force. But then, the total labor force is defined as the number of people employed plus the number of people unemployed within the age bracket of 18-60 years". There is an observed weakness in this definition of unemployment as there are gross variations in the unemployment statistics in Nigeria across various years as published by the National Bureau of Statistics (NBS).

Furthermore, the calculation of unemployment rates in Nigeria by the National Bureau of Statistics (NBS) is strictly one variant of unemployment known as Open Unemployment. According to Todaro [20], open unemployment involves people who are able and often eager to work but for whom no suitable jobs are available.

Open unemployment in Nigeria is measured as:

$$
\mathrm{UR}=(\mathrm{U} / \mathrm{LF}) 100 \%
$$

Where:

$\mathrm{UR}=$ Unemployment rate

$\mathrm{U}=$ Number of unemployed persons

$\mathrm{LF}=$ Total Labor Force.

Unemployment (Open) in Nigeria as of 2012 was estimated to be $25 \%$, about 42.6 million people out of an estimated total labor force of 170 million Nigerians as averred by Okechukwu [14]. It is imperative to mention that open unemployment does not give a true and fair picture of the unemployment rate in the country. This fact is associated with the following reasons- the calculation is based on a snapshot exercise done within a short period (in weeks). Also, it excludes other categories of human resource wastages such as underemployment, low wage employment, the socially excluded workforce, contract employment, and the unemployable. The prevalence of inaccurate statistical records of the unemployed persons constitutes serious impediments to economic and manpower planning in Nigeria. In recent years, insecurity challenges in the country have made it practically impossible for National Bureau of Statistics researchers to collect data on the unemployed from certain parts of the country. For instance, the 2018 unemployment figure in Nigeria of $40.1 \%$ excluded Borno State due to lack of access as a result of insecurity, hence the seemingly drop in the unemployment rate from $61.2 \%$ in 2017 to $40.1 \%$ in 2018. Albeit this challenge, successive governments in Nigeria has made efforts in tackling the unemployment malaise either directly or indirectly through various policies and programs which appeared to have made infinitesimal impacts. Such programs include the National Directorate of Employment (NDE) set up in 1986; Millennium Development Goals (MDGs) which was a product of the year 2000 UN Millennium Declaration and the National Poverty Eradication Program (NAPEP) introduced in 2001, NEEDS (I\&II), the Subsidy Re-Investment Program (SURE-P) and various "Skills Acquisition/Empowerment" schemes. The SURE-P, a product of the MDGs, launched by the administration of the President, Goodluck Jonathan in October 2012, was created to generate employment for the unemployed graduates in the country. Peter [16] said the focus was to create an avenue for 50,000 unemployed graduates as target per year to be attached to firms and organizations where they can work as interns and gain experience for a year with monthly allowances paid by the Federal Government. He averred that the program from its inception in October 2012, had about 120,000 graduate interns enrolled into the scheme. Admittedly, this measure by Government is not pragmatic and has not been able to solve the problems of unemployment in Nigeria. In the first instance, the SURE-P only offers employment to unemployed graduates as interns to acquire experience and receive allowances for a year. The big question is, how many of those 50,000 graduate interns were given jobs by the firms, companies, or government parastatals? Furthermore, about 4.5million students are estimated to graduate from tertiary institutions into the Nigerian labor market annually. This implies that it will take the SURE-P scheme an average of 90 years to absorb the new entrants. This is not only ridiculous but a far cry for a nation that has as her vision 2020 target the generation of 75 million jobs. Anyanwu [4] corroborated this by asserting that "It is not without reason that many are saying that all these government-sponsored job creation and poverty reduction schemes and programs share a common destiny of publicity blitz and gradual fizzling out from the scheme of governments' priorities".

\section{Theoretical Framework}

The theoretical framework employed is the General Theory of Employment by the Keynesian school of thought in 1936. This theory is relevant as it addresses unemployment. According to Keynesian School, total employment is a function of aggregate effective demand for labor. Conversely, unemployment exists when there is disequilibrium in the economy. That is when the demand for labor aggregate is less than the aggregate supply of labor. The resulting unemployment is known as Demand deficient unemployment This is also called cyclical unemployment as it changes with the business cycle. For instance, during the period when the economy is experiencing a boom, the demand for labor will increased and the demand deficient unemployment at this stage of the cycle will be low. When the economy slows down, the supply of labor will be more than demand for labor, thus widening the demand deficient unemployment gap.

This concept of demand deficient unemployment can also be explained using the sketch below. The assumption here is 
the existence of a perfect market. At the equilibrium wage $\mathrm{W}_{\mathrm{e}}$, demand for labor equals supply, $\mathrm{Q}_{\mathrm{e}}$ at the equilibrium point $\mathrm{E}$. Above $\mathrm{W}_{\mathrm{e}}$, that is, at $\mathrm{W}_{1}$, more labor is supplied to the labor market for employment than firms in the industry can efficiently employ. Below $\mathrm{W}_{\mathrm{e}}$, that is, at $\mathrm{W}_{1}$, demand for labor outweighs supply and, firms find it profitable to employ labor.

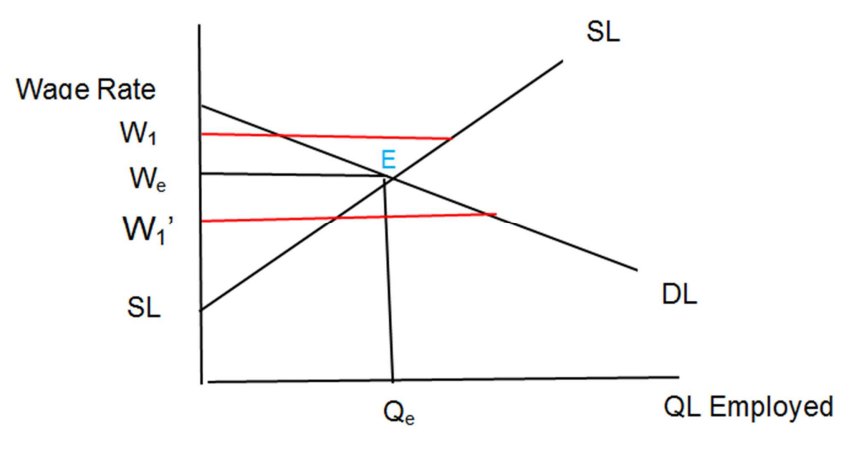

Source: Author

Figure 1. Labour Market.

Under perfect competition, the higher the wage, the higher the supply of labor. Conversely, the lower the wage the higher the demand for labor. Above equilibrium point $\mathrm{E}$, the demand for labor is lower than the supply of labor, leading to a surplus situation and below the equilibrium point $\mathrm{E}$, the demand for labor outweighs supply and this represents a shortage situation. Therefore, the equilibrium point $\mathrm{E}$ represents where supply of labor equals demand. This is full employment. In reality, the attainment of full employment is not feasible by the mere workings of the economic forces, rather the theory envisages as a recipe, the need for government to embark on meaningful programs to bridge the yawning gap of unemployment.

\subsection{Unemployment - Poverty Linkage}

It is relevant to examine the unemployment-poverty linkage since there is a correlation between the two variables. In most developing economies, there exist a positive relationship between unemployment and poverty. That is, as the unemployment rate rises, the poverty rate also rises, and conversely, the poverty rate falls following a decline in the unemployment rate. This relationship is further reinforced by Umoh [21] that " there is no way a poor person can sustainably get out of poverty, no matter how broadly defined, without having a means of livelihood, which is employment (paid or self-generated). Yet most documented poverty reduction strategies hardly mention the word 'employment'. Sawhil [19], in a speech titled 'The Connection between Unemployment and Poverty rates in the U.S argued that the best way to decrease the poverty level in the United States is to provide job opportunities for all adults. This trend was supported by Grunewald [8] based on national data collected in the US that poverty rates have moved somewhat together with changes in the unemployment rate since 1959, and in opposite directions to changes in inflation-adjusted median income. That is, lower poverty rates coincide with decreases in unemployment or increases in income. From the foregoing, any meaningful strategy adopted by the government to tackle poverty without serious consideration to addressing the menace of unemployment constitutes an exercise in futility.

\subsection{Causes and Effects of Unemployment}

Declining quality of education in the three tiers (primary, secondary and tertiary) of our educational system has been adduced to contribute to the rising profile of the unemployment rate in Nigeria. The inability of some graduates to express themselves succinctly during job interviews lay credence to this falling standard of education. To make matters worse, the use of antiquated and moribund school curriculum has also been blamed for the production of graduates whose talents cannot match the current realities of the emerging labor market.

Table 1. Percentage Budgetary Allocations to Education and Health Sectors in Nigeria (1999-2018).

\begin{tabular}{lll}
\hline Year & Education (\%) & Health (\%) \\
\hline 1999 & 13.14 & 10.29 \\
2000 & 12.24 & 6.15 \\
2001 & 10.29 & 8.77 \\
2002 & 13.19 & 9.28 \\
2003 & 7.28 & 4.71 \\
2004 & 8.56 & 5.5 \\
2005 & 8.56 & 6.99 \\
2006 & 10.02 & 6.94 \\
2007 & 10.34 & 7.4 \\
2008 & 10.07 & 7.79 \\
2009 & 7.25 & 5.07 \\
2010 & 4.83 & 3.14 \\
2011 & 6.16 & 4.09 \\
2012 & 8.20 & 5.84 \\
2013 & 8.55 & 5.59 \\
2014 & 9.94 & 5.33 \\
2015 & 7.74 & 5.13 \\
2016 & 6.10 & 4.13 \\
2017 & 7.39 & 4.14 \\
2018 & 7.03 & 3.90 \\
Ave. & $8.84 \%$ & $6.27 \%$ \\
\hline Source: & Statistical Bulletin & Various), Budget \\
www.budgetoffice.gov.ng & \\
& &
\end{tabular}

Also, poor funding of education by the government has to a large extent, contributed to the organic decay in the educational system with the resultant negative impact on unemployment. For instance, the percentage budget allocation to education and health sectors declined from $13.14 \%$ and $10.29 \%$ in 1999 to $7.74 \%$ and $5.13 \%$ in 2015 respectively, during the currency of the MDGs, and this disturbing trend continued till 2018 with budgetary allocations to education and health sectors standing at $7.03 \%$ and $3.90 \%$ (Table 1). It will be recalled that in April 2001, the African Union (AU) met in Abuja and as part of their declaration, now known as the Abuja Declaration, pledged to allocate $15 \%$ of government budgetary to the health sector. In the same vein, the United Nations Educational, Scientific and 
Cultural Organisation (UNESCO) [22] recommended in its 2015 report that 15 to 20 percent should be allocated to education in the national budgets of developing countries. Against these benchmarks, the country's budgetary allocations to these two critical sectors that are drivers of any economy keep declining year on year, with an average of $8.84 \%$ and $6.27 \%$ for education and health for the past two decades (1999-2018). Without gainsaying, it may be difficult for the country to witness any considerable level of development with the persistent funding gap to these two sectors.

The trend analysis of the budgetary allocations to the education and health sectors is as shown below in figure 2 .

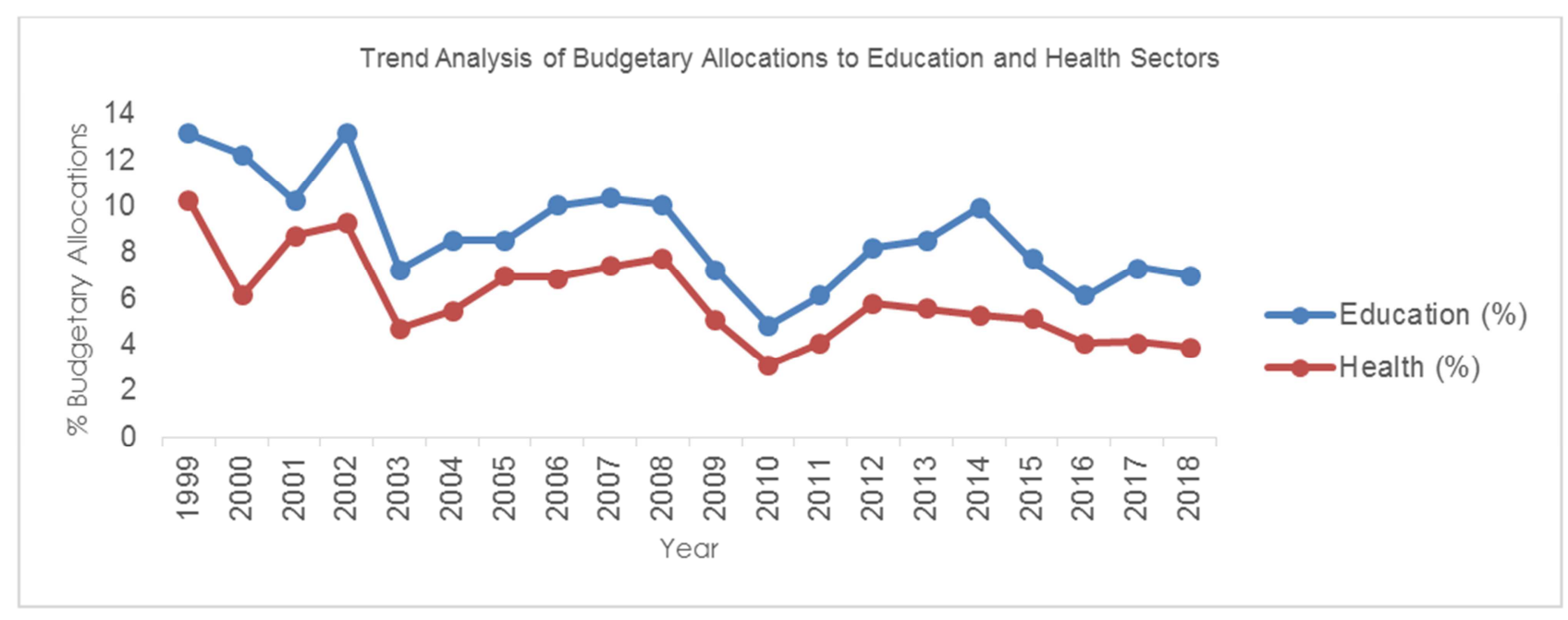

Figure 2. Trend Analysis of Budgetary Allocations to Education and Health Sectors in Nigeria (1999 - 2018).

The poor budgetary allocations to education and health sectors are indicative of the lips service by the government towards ensuring inclusive growth, as no nation attains development without priority attention given to education and the health of its citizens.

The failure of industrialization to create employment for the unemployed labor force is another factor that has accounted for the unemployment situation in Nigeria. The reason put forward by scholars is that industrial production in Nigeria has tended to be highly capital intensive. Sakong [18] in a comparative study of productive efficiency and labor absorption over time in developed and developing economies (Nigeria inclusive) came up with the findings that the manufacturing sector of the developing economies was about as highly capital intensive as that in more developed economies (MDEs) with quite a dissimilar factor endowment. There is no doubt the fact that Nigeria is labor abundant nation and therefore, should encourage laborintensive strategies and production methods to reduce unemployment to the tolerable limit. This milestone will not happen until Government vigorously pursue investment in infrastructures that will generate productive employment for the citizens.

The mismatch between high rates of population growth and sluggish economic growth, with the failure of the latter to translate to economic development, accounts for the rising trend of unemployment in Nigeria. This characteristic is consistent with most developing economies, Nigeria inclusive. The National Bureau of Statistics reported that between 2004 and 2010, the population of Nigeria grew from 139.2 million to 158.6 million (about $13.9 \%$ rise). For the reference period, the average annual growth rate of Nigeria's economy was over of $6.6 \%$. The United Nations (UN) perspective of development asserts that if a country assumes a growth rate of $6 \%$, such a country is said to be developed. It is on record that Liberia exceeded this growth target without development. Also, the situation where Nigeria had a growth rate of $6.6 \%$ while the citizens are almost on the verge of strangulation by unemployment, poverty obscurity, and distinct inequality is yet another paradox to the UN perspective, equating growth with development. It is therefore imperative to state that economic growth, while a necessary condition for development, is not sufficient to address the basic development issues such as unemployment, poverty, and inequality in the developing economies.

Whilst mentioning few causative factors of unemployment, it is pertinent to acknowledge that unemployment has exacerbated debilitating effects on the lives of the average Nigerians and the economy at large. On the severity of unemployment, President Jonathan in his 2013 budget speech asserted that "unemployment constitutes an obstacle to sustainable development as it limits improvement in living standards, output and social cohesion which are key factors for achieving inclusive growth. Our challenge, therefore, transcends how to achieve growth. Our objective is to achieve inclusive growth by identifying and developing job creation opportunities".

Unemployment is considered a threat to the economic, social, and political stability of Nigeria. As the proverbial adage goes " an idle mind is the devil's workshop", the youths who are not engaged in productive ventures have been 
unduly exposed to social vices such as armed robbery, scam, kidnapping, the spring of Niger Delta militancy, and insurgency. They have also been used by money bags politicians during electoral campaigns to perpetrate electoral violence, thus heating the polity. It is undoubtedly true that this unwholesome development has served as a disincentive to foreign investment in our nation.

Unemployment is a critical driver of poverty in Nigeria. There is a somewhat direct relationship between unemployment and poverty rates. There is evidence that as the unemployment rate increases, the poverty rate tends to move in the same direction, thus showing a positive trend. According to Umo [21], employment is a well-known determinant of poverty. This is because one needs a certain level of income generated by work to be able to get out of poverty. If there is no means of livelihood either in terms of paid employment or self-employment, one will therefore face a poverty situation. It is indeed worrisome that over $40 \%$ of Nigerians live below the poverty line, while its leaders (political office holders) live in affluence through humongous salary payments and allowances that are out of synch with what their counterparts in other developing and developed countries are taking, thus making the cost of governance astronomically high in Nigeria. The impact of corruption by the same political elites has also helped in putting the citizenry in a poverty trap. This is indicative of a fragile state (one where structures of governance are weak) and there is a likelihood that Nigeria might lose its traction and stumble into a failed state (one where the government and governance structure is unable to sustain law and order as well as provide for the civilized basic needs of her citizens) if the present trend of poverty is left unchecked.

\section{Evaluation of MDGs Impact on Unemployment}

This focuses on the assessment of unemployment before (1985-1999) and during (2000- 2015) the millennium development goals (MDGs). The evaluation is qualitative, to determine the trend analysis of unemployment during the currency of the MDGs (2000-2015). This will provide a leading as to whether or not the MDGs helped to reduce unemployment.

The period, 1985-1999, before the implementation of MDGs witnessed a stable rate of unemployment in Nigeria, with the highest unemployment rate of $7.1 \%$ in 1987 while the average rate for the referenced period stood at $3.74 \%$. The relative stability of the unemployment rate before the introduction of MDGs is direct evidence that the low rate of unemployment was attributed to other variables or macroeconomic management other than the impact of MDGs.

MDGs were introduced in the year 2000, in which year unemployment rate jumped from $3.0 \%$ in 1999 to $13.1 \%$, representing an increase of over $300 \%$. During the period of the MDGs (2000-2015), unemployment assumed two digits, increasing from $13.1 \%$ in 2000 to $26.8 \%$ in 2015 , averaging about $17.7 \%$. This is contrary to the expectation that with the implementation of the MDGs programs, the rate of unemployment will witness a progressive decline over the years, instead, the contrary was the case. This finding is a clear indication that MDGs did not in any way have any positive effect on the creation of employment and/or reduction of unemployment. The trend analysis in figure 3 attests to the fact that the MDGs failed to reduce the unemployment rate in the country, as evidenced by its rising trend for the period of the MDGs (2000-2015). There is no gainsaying the fact that the government lacked direction and focus on how to tackle the unemployment menace in the country through the MDGs. This is shown by the introduction of employment, which is a critical variable for inclusive growth, as a mere target under the goal of complete eradication of poverty.

Table 2. Unemployment and Poverty Rates (1985- 2018).

\begin{tabular}{|c|c|c|}
\hline Year & Unemp. Rate & Pov. Rate \\
\hline 1985 & 6.1 & 46.3 \\
\hline 1986 & 3.9 & 46.0 \\
\hline 1987 & 7.1 & 45.4 \\
\hline 1988 & 5.3 & 45.0 \\
\hline 1989 & 4.4 & 44.5 \\
\hline 1990 & 3.5 & 44.0 \\
\hline 1991 & 3.1 & 43.5 \\
\hline 1992 & 3.4 & 42.7 \\
\hline 1993 & 2.7 & 49.0 \\
\hline 1994 & 2.0 & 54.7 \\
\hline 1995 & 1.8 & 60.0 \\
\hline 1996 & 3.4 & 65.6 \\
\hline 1997 & 3.2 & 65.5 \\
\hline 1998 & 3.2 & 69.5 \\
\hline 1999 & 3.0 & 72.0 \\
\hline 2000 & 13.1 & 74.0 \\
\hline 2001 & 13.6 & 83.1 \\
\hline 2002 & 12.6 & 88.0 \\
\hline 2003 & 14.8 & 71.2 \\
\hline 2004 & 13.4 & 54.4 \\
\hline 2005 & 11.9 & 54.4 \\
\hline 2006 & 12.3 & 54.4 \\
\hline 2007 & 12.7 & 54.4 \\
\hline 2008 & 14.9 & 54.1 \\
\hline 2009 & 19.7 & 46.0 \\
\hline 2010 & 21.1 & 69.0 \\
\hline 2011 & 23.9 & 68.0 \\
\hline 2012 & 27.4 & 35.2 \\
\hline 2013 & 20.1 & 33.1 \\
\hline 2014 & 24.3 & 43.3 \\
\hline 2015 & 26.8 & 60.0 \\
\hline 2016 & 13.4 & 38.8 \\
\hline 2017 & 18.8 & 61.2 \\
\hline 2018 & 23.1 & 40.1 \\
\hline
\end{tabular}

NB: 2018 Poverty rate excludes Borno State.

Source: CBN Statistical Bulletin (various). NES Annual Conference of 2006. Escaping Poverty in Africa, Umo P. 15. NBS Labour Force Statistics. Vol. 1 (Q4 2017-Q3 2018). 


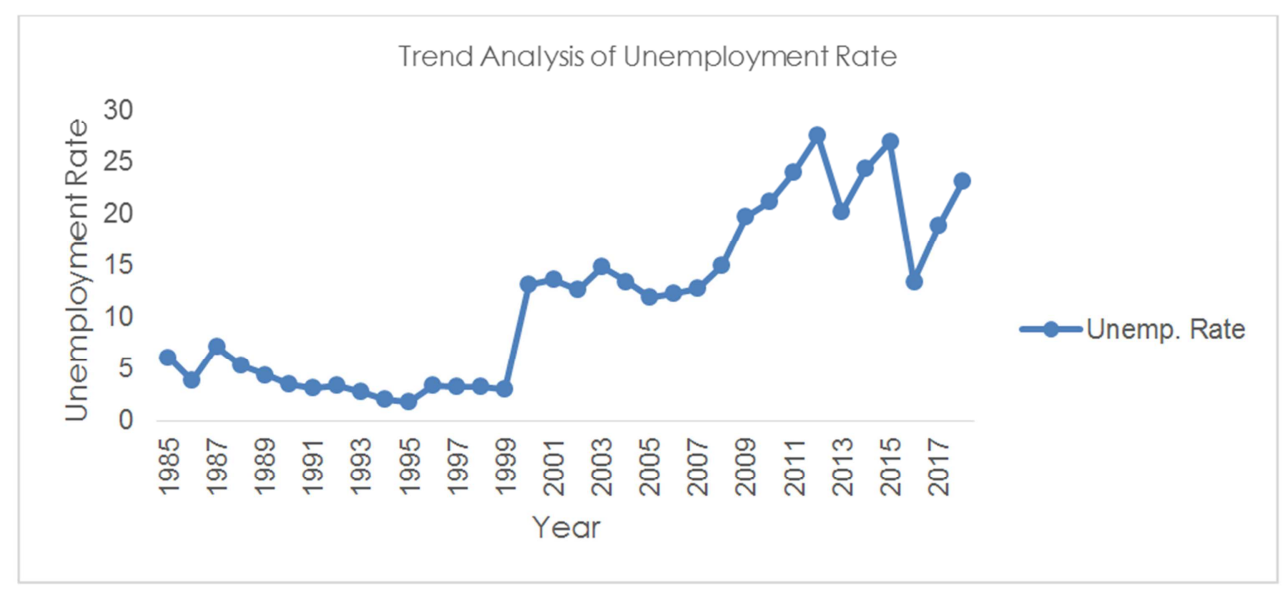

Figure 3. Trend Analysis of Unemployment Rate in Nigeria (1985 - 2018).

Secondly, the paper revealed that there is somewhat a positive correlation between unemployment and poverty. That is, a decrease in the unemployment rate will coincide with a decrease in the poverty rates. However, it is sad to note that MDGs woefully failed to address the issue of poverty eradication as records show that poverty reached an all-time high of $88.0 \%$ in 2002, two years after the implementation of MDGs as indicated in figure 4. For the period of the MDGs (2000-2015), the poverty headcount rate averaged 58.9\% compared to $52.9 \%$ before implementation of the MDGs (1985-1999), a clear indication of the failure of the MDGs to reduce or eradicate poverty which was its main goal.

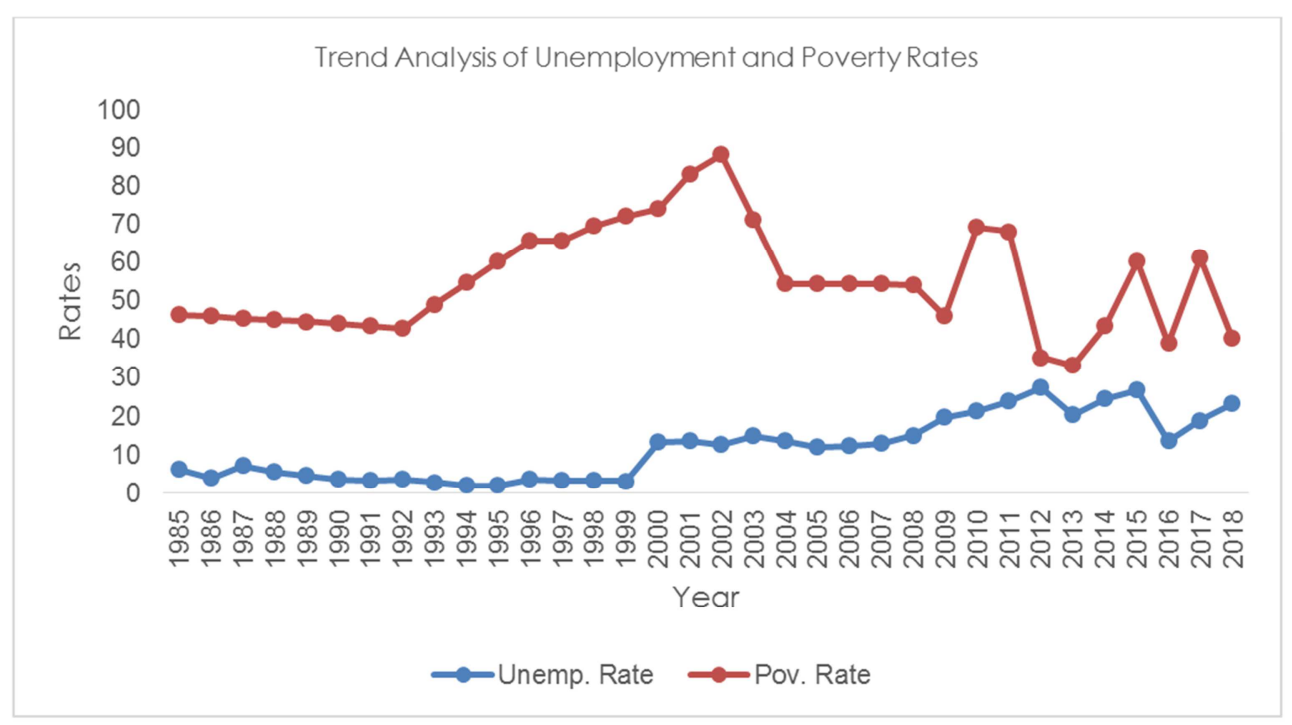

Figure 4. Trend Analysis of Unemployment and Poverty Rates in Nigeria (1985 - 2018).

\section{Why the MDGs Failed to Address Unemployment Issues in Nigeria}

Our findings support the consensus in Nigeria that the MDGs agenda failed to address the twin developmental challenges - unemployment and poverty in Nigeria. The conceptual framework of the MDGs was faulty ab initio. For instance, the agenda did not have as one of the eight (8) goals, the creation of productive employment or 'eradication' of unemployment in Nigeria; rather, employment creation was only brought in as a sub target in 2005 after the review of the program. This is indicative of an outright faulty action plan which did not take into consideration that employment creation is an inclusive growth strategy with enormous impacts on other developmental indices.

The target set for the creation of decent employment for the youths and women were non-metric, instead, the MDGs target for employment creation was just qualitative in nature, which makes quantitative measurement and monitoring difficult. Any meaningful economic or business target must be quantitatively measured, so that deviations (whether positive or negative) could be accounted for and corrective actions put in place. The non-metric employment target was a serious oversight on the part of the managers of the program and this might not be farfetched from the usual popularity blitz of government that soon fizzles into the thin air.

The programs of the MDGs suffered institutional setbacks 
arising from poor and uncoordinated disbursement of funds. For instance, in 2005, Nigeria secured a debt relief of eighteen billion U.S dollars (USD18 billion) from the Paris Club under the leadership of President Olusegun Obasanjo and the support of the Finance Minister, Dr. Ngozi OkonjoIweala.

The debt relief was without its conditionality, aimed at controlling the use of the gains from the good gesture of the Paris Club. The modality was that one billion dollars (\$1billion) will be disbursed to the government of Nigeria on an annual basis for developmental projects, using the MDGs as a vehicle. For effective management of the savings from the debt forgiveness, the President set up the Office of the Senior Special Assistant to the President on MDGs (OSSAP-MDGs), an office equivalent to that of a junior Minister, with the responsibility of reporting directly to the president.

The disbursement of funds for programs under the MDGs took effect in 2006 and there is evidence to the fact that some projects earmarked were either not implemented or abandoned due to funds disbursement hiccups. For example, the fertilizer manufacturing plant using recycled wastes located at Igberem Community in Ogun State was abandoned five years after President Olusegun Obasanjo left office in 2006, while the plant that was to be located in Maiduguri, Borno State did not see the light of the day.

Undoubtedly, if these infrastructural projects were successfully implemented, they would have resulted in the creation of productive employment for unemployed youths and positively impact poverty reduction. The spate of projects abandonments is not strange to the developing countries, but this is consistent with the character of project implementations in Nigeria.

\section{Conclusion and Recommendations}

The paper sets out to assess the unemployment rate before and during the Millennium Development Goals (MDGs) and the extent to which MDGs have helped in the 'eradication' of this macroeconomic problem in Nigeria. Conceptually, many scholars (notably pro MDGs) are of the view that the program has recorded a measure of success in the creation of employment or reduction of unemployment since its implementation in the year 2000 .

Our findings attest to the contrary, as unemployment rates in Nigeria during the currency of this program peaked at $27.4 \%$ in 2012 with an average of $17.7 \%$ compared to an average of $3.74 \%$ before the implementation of MDGs (1985-1999). Its effects no doubt had been very unsavory, ranging from poverty precipitation to the constitution of a threat to the economic, social, and political stability of the country. Consequently, the pursuit of inclusive growth by various administrations without concrete remedial action to tackle unemployment had been a mirage. Unfortunately, the MDGs program, which was seen as the much-awaited messiah, has in the past 15 years of its implementation failed to deliver on target.
Since the MDGs 2015 deadline has come and gone, it becomes imperative to draw the following lessons/recommendations that will serve not only as policy prescriptions but also as insights to the Post-2015 Global Development Agenda.

i. The creation of employment for youths and women was to be a goal and not a sub-target in the MDGs.

ii. The goal should have been measurable quantitatively instead of qualitatively, to enhance the evaluation of the MDGs achievement.

iii. Full monitoring and evaluation of projects which was lacking in MDGs 2000- 2015 should be put in place to avoid a repeat of similar failure experiences.

iv. The implementation of MDGs programs should, to a large extent, be divorced from civil service bureaucracies and private participation should be encouraged for a blend.

v. Implementation of laudable infrastructural projects of various government administrations should follow a continuum to avoid project abandonment that often leads to monumental waste of resources/ project outlay.

vi. The MDGs program did not take into cognizance the likely effect of violence, militancy, and insurgency on development in trying to address the twin developmental challenges- poverty and unemployment as their goal and sub-target. The Post-2015 Global Development Agenda should critically consider these variables as they constitute a threat to sustainable development.

\section{References}

[1] Adebayo, A. (1999). Youth Unemployment and National Directorate of Employment: Self Employment Programmes. Nigerian Journal of Economics and Social Studies, 4 (1).

[2] Adedipe, B. (2004). The Impact of Oil on Nigeria Policy formulation. Paper presented at a conference on Nigeria: Maximizing Pro-poor growth organized by Overseas Development Institute in conjunction with Nigeria Economic Summit Group, June $16^{\text {th }}-17^{\text {th }}$.

[3] Akinboyo, G. B. (1987). Job Creation as a Productivity Measure for Employment Problems in Developing Countries: The Nigeria and Holland Experience, Increasing Productivity in Nigeria. Lagos: National Productivity Centre, p 404-411.

[4] Anyanwu, T. V. C (2014). 2014 Budget and Job Creation: Perform or Resign, Sahara Reporters, January 20.

[5] Clinton, B. (1993). President Bill Clinton's Promising Speech. New York Times, November 17, p. 26.

[6] Englama, A. H. (2001). Unemployment Concept and Issues: CBN Statistical Bulletin, Vol. 25 (4).

[7] Gbosi, A. N. (1997). Chronic Unemployment in Nigeria. International Journal of Employment Studies, 5 (1), pp. 155159.

[8] Grunewald, R. (2006). The Connection between Poverty and the Economy. The Economist, November 01 issue. 
[9] Jhingan, M. L. (1999). Macroeconomic Theory, Vrinda Publication Limited, India. $10^{\text {th }}$ Edition, P. 237.

[10] Jonathan, G. (2013). 2013 Budget Speech. Proshare, December 13.

[11] Marlar, J. (2012). Global Unemployment at 8\% in 2011. Gallup Surveys, April 17.

[12] Marx, K. (1863). Theory of Surplus Value. In: Levroro, E. S. Marx on Absolute and relative Wages. MPRA, September, 2000 .

[13] Ohale, L. and Onyema, J. (2001). Foundation of Macroeconomics. Spring Field Publishers, Owerri.

[14] Okechukwu, O. A. (2012). Rising Youth Unemployment and Violent Crime in Nigeria. American Journal of Social Issues and Humanities. 2 (5), pp. 315-321.

[15] Onwioduokit, O. A. (2006). The Character of unemployment in Nigeria and its Link with the Macroeconomy. NES Conference on Employment Generation in Nigeria.

[16] Peter, P. (2013). SURE-P Swings into Action to Reduce Unemployment, Vanguard Newspaper, May 1.
[17] Raheem, M. I. (1993), Nigeria for Africa: A case for labour export. In: Oyejide, T. A., Obadan, M. I., editors. Applied Economics and Economic Policy, in Honor of Emmanuel C. Edozien. Ibadan: Ibadan University Press.

[18] Sakong, I. I. (1971). High Capital Intensity, Productive Efficiency and Employment. Philippine Economic Journal, Vol. 10, No. 1.

[19] Sawhil, I. V. (2011). The Connection between Employment and Poverty Rates. Brookings. September 9.

[20] Todaro, M. (1992). Economics for a Developing World. $2^{\text {nd }}$ edition, England, Longman UK.

[21] Umo, U. U. (2012). Escaping Poverty in Africa: A Perspective on Strategic Agenda for Nigeria. Millennium Text Publishers Limited, Lagos.

[22] UNESCO (2015). Education for All 2000-2015: Achievements and Challenges. EFA Global Monitoring report.

[23] United State Embassy in Nigeria (2012). Fact Sheets.

[24] World Bank (1998). World Development Indicators. The World Bank, Washington DC. 